\title{
Broken Time and Broken Hearts The Maritimes and the Selection of Canada's 1936 Olympic Hockey Team
}

by

Mark Savoie

BSc UNB 90. MA UWO 94

A Report Submitted in Partial Fulfilment of the Requirements for the Degree of

\section{Master of Arts}

in the Graduate Academic Unit of History

Supervisor.

Ernest R. Forbes. PhD. History

Examining Board: Stephen E. Patterson. PhD. History. Chair

Phillip A. Buckner, PhD. History

J. Marc Milner. PhD. History

THE UNIVERSITY OF NEW BRUNSWICK

April 1997

@Mark Savoie 1997 
National Library
of Canada

Acquisitions and Bibliographic Services

395 Wellington Street Ottawa ON K1A ON4 Canada
Bibliothèque nationale

du Canada

Acquisitions et

services bibliographiques

395, ne Wellington

Ottawa ON KIA ON4

Canada
The author has granted a nonexclusive licence allowing the National Library of Canada to reproduce, loan, distribute or sell copies of this thesis in microform, paper or electronic formats.

The author retains ownership of the copyright in this thesis. Neither the thesis nor substantial extracts from it may be printed or otherwise reproduced without the author's permission.
L'auteur a accordé une licence non exclusive permettant à la Bibliothèque nationale du Canada de reproduire, prêter, distribuer ou vendre des copies de cette thèse sous la forme de microfiche/film, de reproduction sur papier ou sur format électronique.

L'auteur conserve la propriété du droit d'auteur qui protège cette thèse. $\mathrm{Ni}$ la thèse ni des extraits substantiels de celle-ci ne doivent être imprimés ou autrement reproduits sans son autorisation. 


\begin{abstract}
The Halifax Wolverines were the Allan Cup winners of 1935. giving them the right to represent Canada at the 1936 Winter Olympic Games in GarmischPartenkirchen. This right was stripped from them, however. when central Canadian hockey ofticials complained that the Maritimes hockey teams had been violating the Canadian Amateur Hockey Association's strict residency requirements. The Wolverines first saw their league forced to disband and then saw the same of their team. the Olympic bid instead went to the runner-up Port Arthur Bearcats of Ontario. Four remaining plavers from the Wolverines were allowed to join the Bearcats for the Olympic trip. but were summarily dismissed from the team two weeks prior to departure on the grounds that they had asked for pay for time lost from work.
\end{abstract}

Maritimers were furious. They saw within these events the exercise of central Canadian bias against the Maritime provinces reminiscent of their earlier struggles for national recognition in the political agitation known as the Maritime Rights Movement. That had seemed to find vindication in the recommendations of the Duncan Commission of 1926. but their victory had proved hollow in the continued disparity of the depression of the 1930s.

Maritimers joined their compatriots in the West in asking why the Canadian Amateur Hockey Association was now applying an outdated definition of amateur status which had not been enforced for years. Central Canadians. on 
the other hand, insisted that such a definition was necessary to avoid creeping professionalism. The CAHA voted to allow broken time payments, however, once the Bearcats returned from Germany without a gold medal. This change came too late to help the Maritimes, who bitterly resented the destruction of their chance for Olympic glory. 
On 17 April 1935 the Halifax Wolverines defeated the Port Arthur (Ontario) Bearcats 4-3 in the Halifax Forum to capture the Allan Cup. the emblem of senior ice hockey' supremacy in Canada. This was not just a victory for the Woiverines and Halifax. it was also a victory for the Maritimes. Not only was it the third consecutive vear that the Allan Cup had been claimed by a Maritime team. but tradition now dictated that Canada would be represented by the Halifax Wolverines at the following year's Winter Olympic Games in Garmisch-Partenkirchen. Germany. Given that Canada had never been defeated in Olympic competition. this suggested that a Maritime team was going to show the world that they were the best amateur hockey team on the planet. Thus. it was with anger and despair that Haligonians watched the Canadian Olvmpic team sail out of Halifax Harbour on 19 January 1936 with nary a Nova Scotian represented. The hockey team was now a collection of all-stars drawn from Ontario and Quebec (plus one from North Battleford. Saskatchewan), ostensibly representing Canada as the Port Arthur Bearcats. There was not a single Wolverine on board. Senior ice hockey was and is the highest level of ostensibly amateur hockey in Canada 
Maritimers viewed this absence as an act of treachery by central Canadian họkev officials - just another example of the Maritimes being cheated of their rights by central Canada.

Ronald S. Lappage looked at the issue of regional discontent in the world of sports as early as 1974 . He found that sportsmen from both the western and eastern provinces resented what they perceived to be Ontario's dominance of Canadian sport. Similar to the sense of injustice felt when the supposedly national economic policies of the federal government worked to the detriment of the peripheral provinces, was the widely held belief that Ontario influences within the national sporting organisations worked against Westem and Maritime athletes. They held this to be especially true of national championships. with favouritism routinely given to athletes from central Canada. This was even more evident. they believed. during Olympic years. when western or eastern athletes were alternatively ignored or wooed by the Ontario sporting bodies. Victories over teams or athletes from Ontario thus took on a special significance. particularly when those victories also meant a national championship.'

"Ron Lappage, "Sport Between the Wars" in Don Morrow, Mary Keyes. Wayne Simpson. Frank Cosentino. and Ron Lappage. eds.. A Concise History of Sport in Canada. (Toronto. Ontario: Oxford University Press. 1989), pp. 88-108: Ronald S. Lappage. "Selected Sports and Canadian Society 1921-1939." unpublished PhD dissertation. (Edmonton. Alberta: University of Albetta. 1974): Ronald S. Lappage. "Sport as an Expression of Western and Maritime Discontent in Canada Between the Wars" in ('anadian Journal of Histony of Sport and Phisical Eclucation. 8 : 1 (May 1977). pp. 50-71. Echoes of regional discontent can also be found in the few recent accounts of the sport history of the Maritimes. See Robert Ashe. Even the Babe (ame in Plar: 
Lappage wrote his dissertation before much of the historical literature on the regional discontent in the Maritimes had appeared. there being little other than G. A. Rawlyk's brief and unsympathetic account. ${ }^{3}$ Since then, however, Maritime regionalism. particularly the Maritime Rights Movement. has received considerable scholarly attention. Regional historians have shown that the Maritime provinces were not only vociferous and active in their attempts to improve their lot within Canada, but were also remarkably successful given the limited political pressure they could bring to bear in the House of Commons. They succeeded in part because a sustained campaign of newspaper propaganda convinced Maritimers of the justice of their position and won sympathy in other parts of the country. The supposed implementation of the recommendations of the Duncan Commission of 1926 gave both Maritimers and other Canadians the impression that the region's economic problems had been alleviated. When this impression proved illusory in the worsening depression of the 1930s. their western neighbours tended to view the renewed Maritime complaints as akin to begging. However, while Maritime protests in the 1930s did not vield the positive

Small-Town Baseball in the Dirty 30s, (Hatifax. Nova Scotia: Nimbus Publishing. 1981). pp. vi-vii: Colin Howell. Northern Sandlots: A Social Histon of Maritime Baseball. (Toronto. Ontario: University of Toronto Press. 1995), pp. xiii. 158-159. 229.

'G. A. Rawlyk. "Nova Scotia Regional Protest. 1867-1967” in Queen's Quarterly. $75: 1$ (Spring 1968). pp. 105-123. An early more sympathetic account is Michael Hatfield. JJ. B. M. Baxter and the Maritime Rights Movement." unpublished BA report. (Sackville. New Brunswick: Mount Allison University. 1970). 
results of the previous decade. the pervasive local sense of iniustice which underlay them endured. ${ }^{+}$

This sense of injustice transferred easily to the sports theatre and offered an immediate explanation for the Maritimes' failure to secure Olympic representation. From an Ontario perspective, however. the operative concern was not region but class. Canadian Amateur Hockey Association (CAHA) officials were fighting to preserve the concept of gentlemanly amateurism against a

"Sympathetic accounts of the movement include Margaret Conrad "The Art of Regional Protest: The Political Cartoons of Donald McRitchie. 1904-1937" in .Acadiensts. 21: I (Autumn 1991). pp. 5-29: E. R. Forbes. "The 1930s: Depression and Retrenchment" in E. R. Forbes and D. A. Muise, eds., The fllantic Provinces in C'onfederation. (Toronto. Ontario: University of Toronto Press. 1993). pp. 272-305: Emest R. Forbes. Challenging the Regional Stereotype: Fssays on the 201th ('entury Maritimes. (Fredericton. New Brunswick: Acadiensis Press. 1989). pp. 100-113. 148-171: Emest R. Forbes. The Maritime Rights Movement. 1919-1927: A Stuct. in (anadian Regionalism. (Kingston. Ontario: McGill-Queen's Liniversity Press. 1979): Kenneth Gary Jones. “Response to Regional Disparity in the Maritime Provinces. 1926-1942: A Study in Canadian Intergovernmental Relations." unpublished MA thesis. (Fredericton. New Brunswick: University of New Brunswick. 1980). For Marxist interpretations of the movement see James Bickerton. "Underdevelopment and Social Movements in Atlantic Canada: A Critique" in Studies: in Political Economy: A Socialist Review. no. 9 (Fall 1982). pp. 191-202: James P. Bicketton. Vova Scotia. Ottania. and the Politics of Regional Development. (Toronto. Ontario: Lniversity of Toronto Press. 1990): Robert J. Brym and R. James Sacouman "Introduction” in Robert J. Brym and R. James Sacouman. eds.. Cinderdevelopment and Social Movements in Atlanic Canada. (Toronto. Ontario: New Hogtown Press. 1979). pp. 9-14: David Frank. “The 1920s: Class and Region. Resistance and Accomodation" in E. R. Forbes and D. A. Muise. eds.. The Allantic Provinces in Confederation. (Toronto. Ontario: University of Toronto Press. 1993). pp. 233-271. 
creeping protessionalism which to them seemed particularly apparent in the recruitment and behaviour of teams from the Maritimes.

It was against a background of intense regional consciousness that the Maritime Amateur Hockey Association (MAHA) affiliated itself with the CAHA in 1927. Such affiliation was necessary, as only then could the MAHA's champion team challenge for the Allan Cup. At first Maritime teams had little success. After five years of Allan Cup play they had put together an unimpressive record of one win. ten losses. and one tie. ${ }^{5}$ Even this. however. had been enough to stir some pride within the Maritimes. Their 1931 representative. the Truro Bearcats. thought (perhaps optimistically) by Maritimers to have a good chance for success in the Allan Cup, had their team shorn of three of its players by the CAHA just days prior to the playdowns. on the grounds that these plavers did not meet the CAHA's residency requirement. ${ }^{\circ}$ Given that the Bearcats' roster had just

The Halifix Herald. (18 Warch 1933). p. 11.

The CAHA in 1930 required that a player be living within the community for which he played by 15 May prior to the hockey season. By 1935 this date was changed to 15 October prior to the ensuing hockey season. However. for transfers of players between the various branches of the C.AHA. the residency requirement was I January prior to the hockey season. unless the C.AHA was satisfied that the player's change of residence was for legitimate non-hockey reasons. such as employment or academic pursuits. There was considerable confusion over the interpretation and enforcement of this rule. See anonymous. 1930 Official Hockey Rules. Canadian Amateur Hockey Association. Constitution By-Lans and Regulations. Rules (joverning .Allan ('up and O.H.A. Memorial Trophy (iames. Playing Rules of the Game. pp. 5-7: anonymous. 1935 ()ffictal Hockey Rules. ('anadian .Amateur Hockey Assoctation. Constitution Bi-Lanis and Regulations. Rules (joverning .Allan (up and O.H..t. Memorial Trophy (iames. Playing Rules of the (iame. 
ten men. this meant that only seven plavers remained to compete for the Allan Cup. Even so thev deteated McGill University in the first round betore succumbing to a team representing Hamilton in the second. The perceived treachery of the CAHA was held to the real cause of their defeat. and the plight of the valiant 'Truro Seven' became part of Maritime hockey lore ${ }^{7}$

The 1932-1933 season saw a much stronger brand of hockey being plaved in the Maritimes. as the teams in the Big Four League (Charlottetown Abegweits. Halifax Wolverines. Moncton Hawks. and Saint John Beavers) each took steps to improve their rosters. They did this by reversing the usual flow of athletes from the Maritimes to Central Canada instead recruiting players from other amateur hockey associations across Canada. The most aggressive recruiters were the Moncton Hawks. who raided Winnipeg of several of that city's best plavers. including standout goalie Jimmy Foster. The Hawks eventually managed to capture the Big Four League championship that season and then easily dispatched competition from the other senior leagues within the MAHA to earn the right to enter the Allan Cup playdowns.

pp. 8-11: "Minutes of the Eighteenth Annual Meeting Canadian Amateur Hockey Association. 1935." (Halifax. Nova Scotia: 10-12 April 1935). G. S. Dudley Files. National Archives of Canada pp. 53-61.

The Halifax Herald. (26 February 1935). p. 5: (1 January 1936). p. 9. 
Maritime iournalists were guardedlv optimistic about the team's chances in light of previous failures. ${ }^{8}$ They felt on the strength of some mid-season victories against Quebec and Ontario teams. that although the Hawks were probably not good enough to win the Allan Cup. they would have a good chance of being the first Maritime team to defeat an Ontario team in the Allan Cup playdowns. ${ }^{9}$ Prior to these playdowns Maritimers reacted strongly against the CAHA's suggestion that the games between the MAHA and the Quebec Amateur Hockey Association's (QAHA) champions. originally scheduled tor the Maritimes. be played in Quebec as an economy measure. Jimmie Smith. Sports Editor of The Halifax Herald. howled with indignant mirth at the thought that the CAHA. which had bragged of its strong financial status despite the depression. could now claim economy at the expense of the Maritimes. "It is quite evident." he argued. that the C. A. H. A. would rather call it quits than see the Allan Cup come to the

This paper makes extensive use of newspaper accounts for its depiction of the events surrounding the Allan Cup playdowns of 1933-1935 and the Winter Olympic Games of 1936. paying particular attention to the several sports columns which were devoted to the subject. The assumption when using editorials of this kind is that they serve to both reflect and mould public opinion. It thus falls upon the historian to interpret these columns and determine the extent to which they do so. In this case the unanimity of opinions expressed by editors of the Maritime newspapers examined leads one to conclude that they were to a considerable degree reflecting the sentiments of Maritime sports fans. To a lesser degree the same observation can be made of the opinions expressed by the sports editors of the newspapers examined for other regions. There is also an unavoidable urban bias inherent in the exclusive use of such newspapers.

The Halifar Herald, (18 March 1933). p. 9. 
Maritimes. ... Thev see in the East this vear an even greater threat Ithan the 10:1 Truro Bearcats! and as an initial move to place a barrier before the Maritime champions. have "suggested" playing the games. scheduled for Eastern Canada. on foreign ice." The MAHA won this dispute and the Hawks" first round games were played in Moncton. They won these games against the Montreal Royals 2-0 and 3-3 (5-3 aggregate) and then travelled to Toronto. where they defeated the Niagara Falls Cataracts $0-1$ and 4-1 (4-2 aggregate) to advance to the finals in Vancouver against the Saskatoon Quakers. A delighted Halifar Herald crowed that the contest between a Maritime team and a Saskatchewan team held in British Columbia represented a true Canadian championship." Jubilation again prevailed in the Maritimes as the Hawks dispatched the Quakers 3-0 and 2-0 to give the Maritime provinces their first Allan Cup.

The 1934 Allan Cup playdowns were almost a duplicate of 1933. First the Moncton Hawks swept to victory in the Big four League and then they crushed all other MAHA opposition. Travelling to Montreal for the quarter finals. they defeated the McGill Redmen $3-1$ and $3-1$ before journeving turther west to Toronto. in Toronto they first defeated the Hamilton Tigers $2-0$ and $1-2,3-2$ aggregate) before eventually beating the Fort William (Ontario) Thundering Herd

ibid. (21 January 1933). p. 11: (24 January 1933). p. 5: (11 February 1933). p. 11.

ihud. (7 April [933). p. 5. 
2-3. 4-2. and 5-1 (for a 2-1 series win). Once again the Allan Cun came to the Maritimes.

Some Ontario officials cried foul. however. arguing that the Hawks were not truly an amateur team. Still, the amateur oath had been given by the Hawks and accepted by CAHA president Frank Greenleaf. so there was little that could be done about the matter. The Halifax Herald acknowledged that the Hawks were not truly amateur. and this had in lact been admitted the previous year. They argued. however. that there was no reason why Maritime clubs should be punished for the practice of paying imported players when this was the common practice of all the clubs which had been involved in Allan Cup competition. ${ }^{12}$

The amateur issue was a serious point of contention in Canadian sport. with hockey being no exception. The concept of amateurism had originally been defined in the latter half of the nineteenth century with the explicit purpose of excluding members of the working class (along with such other unwanted personages as natives and blacks) from participation against and with their social betters. As a result a person's status as an amateur was determined by occupation. This remained the determinant of amateur status until the close of the nineteenth century and the dawn of the twentieth. when there came a gradual shift towards detining an amateur as one who had never competed for money. This detinition was just as exclusionary as was the occupational definition and had the added

\footnotetext{
:bud. (13 April 1934). p. T.(18 April 1934).p. 9.
} 
bonus of avoiding the stigma of an overt class and racial preiudice. The monetary basis for amateurism became especially exclusionary once competition advanced to the national level. National competition required time: time to travel. and time away from work. Thus. a working class athlete who was dependent on each instalment of his pay did not have the option of travelling across the country to play his sport." The International Olympic Committee (IOC) had approved the compromise of broken time payments - payments for time lost from work - in the sport of soccer in 1927. but the Canadian Olympic Committee (COC) looked upon this practice with disdain. preferring to take a hard-line 'simon-pure' stance on amateurism. ${ }^{\text {It }}$ The compromise of broken time payments would have allowed working class athletes to compete at the national level on a more equal footing. They could not do so. however. in Canada. The IOC permitted the practice in the case of soccer. but it was also the IOC's policy to allow any nation's Olympic committee to set more stringent requirements if it so desired. The $\mathrm{COC}$ followed the lead of the Amateur Athletic Union of Canada (AAU of C), whose Official Athletic Rules and Handbook declared that:

"Frank Cosentino. "A History of the Concept of Professionalism in Canadian Sport." unpublished PhD dissertation. (Edmonton. Alberta: Lniversity of Alberta 1973): Keith L. Lansley. "The Amateur Athletic Union of Canada and Changing Concepts of Amateurism." unpublished PhD dissertation. (Edmonton. Alberta: University of Alberta 1971).

'Lansley. "The Amateur Athletic Union of Canada and Changing Concepts of Amateurism." pp. $182-183$ 
An amateur is one who has never: . . 3. Received anv bonus or payment in lieu of loss of time while playing as a member of any club or engaged in any athletic sport or exercise, or any consideration whatever for any service as an athlete. except actual travelling or hotel expenses. ${ }^{15}$

Thus, in Canada the principle of 'simon-pure' amateurism ruled the day. with no compromises allowed.

Such an exclusionary definition of amateur implied that the ultimate goal of sport was for the "love of the game and the friendly spirit of competition." Winning was to be only a by-product of this lofty goal. Unfortunately tor those who held this belief. it quickly became apparent that winning was often more important than how the game was played. especially in those sports in which a profit could be realised by charging an attendance fee. Hockey's Stariley Cup had been intended as an amateur trophy when it was first donated in 1893. but by 1910 it was already being awarded to openly professional teams. In the intervening years many teams had begun the practice of paying plavers under the table. a practice that was both well known and officially ignored. Eventually. the hypocrisy of continuing to declare the winner of the Stanley Cup the amateur champion of Canada was recognised by the Stanley Cup trustees. who offered it to the wholly professional teams of the National Hockey Association (NHA) and the Pacific Coast Hockey Association (PCHA). By the 1930s both of these leagues

anonymous. ()fficial fthletic Rules and Handbook of the Amateur fthlettc tinon of ( anadu $-193^{\top}$. pp. $7-8$. 
were defunct. many of their teams being absorbed into the National Hockey League (NHL). which now had sole claim to the Stanley Cup under the direction of the Stanley Cup trustees. ${ }^{16}$

The Stanley Cup. however. was by the 1930s hardly a national trophy. The NHL in 1933. had nine teams: five in the United States and four in Canada. These four teams were in Montreal (2). Ottawa. and Toronto. At the start of the 1934-1935 season the Ottawa franchise moved to the United States. leaving just three Canadian teams in the league. As a result. although the NHL and Stanley Cup were regarded by Canadians as emblematic of the best hockey in the world. they were not able to engender the same feeling of civic or regional pride as did senior hockey's Allan Cup. At the local level. winning the Stanley Cup was no longer even a fantasy. while the prospect of winning the Allan Cup became a very real dream. It is no surprise. then. that the same pattern of under the table payments became prevalent among competitors for the Allan Cup. Winning had once again become more important than merely competing. and amateurism was shunted aside as an outdated ideal. This was an openly acknowledged and accepted aspect of Allan Cup hockey in the Maritimes. It was also acknowledged in Ontario but was not so universally accepted. ${ }^{17}$ The term 'shamateur' was freely :Stan Fischler and Shirley Walton Fischler. eds.. The Hockey Encyclopedia: The Complete Record of Professional Ice Hockey. (New York. New York: Macmillan Publishing Company. 1983). pp. 2-7.

See Don Morrow. -Lou Marsh: The Pick and Shovel of Canadian Sporting Journalism" in 
used by sports writers of both regions. who often argued that the CAHA should recognise that their definition of amateur (the CAHA. a member organisation of the AAU of C. accepted the AAU of C's definition of the term) did not mesh with the reality of senior hockey. and that they should loosen the restrictions accordingly. Jimmie Smith of The Halifax Herald dealt with this issue immediately after the Hawks' victory in 1933 in response to a letter complaining that the Hawks were not amateurs:

What of it. you might say, if every plaver in Canada was paid during the 1933 hockey season? Do you expect them to play three games a week and get nothing for it? When are they supposed to work? And how are they supposed to live? . . Should they not be paid for the time they devote to hockey. or rather. to giving three. four or five thousand people entertainment? Yet if an athlete is paid for the time he loses from his employment. he is classed as a professional and stands to be suspended. ${ }^{\text {Is }}$

Despite such criticism, the CAHA and the AAU of $C$ staunchly reaffirmed the rhetoric of 'simon-pure' amateurism. Perhaps they feared the challenge to their traditional class values. perhaps. too, they saw compromise as leading towards the slippery slope of professionalism. Whatever their thinking. the practice of broken time payments remained a tacitly accepted but officially banned practice. ${ }^{19}$ ('anadian Journal of History of Sport. 14: I (May 1983). pp. 21-33. for one reporter's crusade against 'shamateurism.'

The Halifar Herald. (25 April 1933). p. 5: (26 April 1933). p. 7: (12 May 1933). p. 7: (13 April 1934). p. 7.

$\because$ thorough account of the amateur ideal with regard to middle class values may be found in Alan Metcalfe. Canada Learns in Play: The Emergence of Organized Sport. I807-1914. 
The winner of the 1935 Allan Cup would not only be recognised as the hest senior hockey team in Canada. but would also win the right to represent Canada at the 1936 Winter Olympics in Garmisch-Partenkirchen. Hockey had been a medal event on four occasions and Canada had won each time. usually by ridiculous margins. Their first serious competition had come in 1932 at Lake Placid. New York when the United States team forced them into overtime in the gold medal game. Thus. 1935's Allan Cup champion could expect extensive national and international recognition and an excellent chance at an Olympic Gold Medal. Soon after the Moncton Hawks won the Allan Cup in 1934 The Halifar Herald pointed out the importance of the Maritimes winning the Cup again the next year because of the upcoming Olympics. ${ }^{20}$ It also mentioned the possibility of trouble from CAHA officials with regard to the Maritimes' imported plavers as central Canadians began to manoeuvre to secure Olympic representation for their athletes."

The prediction of trouble from the CAHA proved to be prophetic. although there is no direct evidence that the difficulties arose because of the Olympics. Frank Greenleaf of Montreal had been replaced by E. A. Gilroy of Portage la

(Toronto. Ontario: MeClelland and Stewart. 1987). especially pp. 99-180.

'The Halifax Herald. (4 April 1934). p. 7.

:ibid. (14 May 1934). p. 9. 
Prairie. Manitoba as president of the CAHA at the end of the 1933-1934 season. and had returned to his position as president of the QAHA. Before the beginning of that season he complained to Gilroy that the teams in the Maritimes' Big Four I.eague were violating the $\mathrm{CAHA}$ 's residency requirement. Gilroy. upon a brief investigation. elected to rule all players in the Big Four League who had not received their transfers prior to 1 January 1934 ineligible for the upcoming season. Maritime hockey officials were aghast at this decision. They pointed out that while the residency rule did in fact exist. it had not been enforced in several years. They also asked why Gilroy had broken from CAHA policy by barring the plavers wholesale instead of dealing with each case on an individual basis."2

This destroyed the Big Four League as an amateur league. Neither the Moncton Hawks nor the Halifax Wolverines were much affected by the decision. but both the Charlottetown Abegweits and the Saint John Beavers saw the bulk of their players declared ineligible. In a desperate attempt to maintain the league and the profits which it was expected to generate. the league officials decided to forego amateur standing as a senior league under the CAHA's jurisdiction. and to become a Mercantile League exempt from the CAHA's guidelines. Of course. this meant that the Allan Cup and the Olympics were out of reach. but the league

Fibid. (24 October 1934). p. 9: (31 October 1934). p. 9: (1 November 1934). p. 9: (1 November 1934). p. 11: Lappage. “Selected Sports and Canadian Society 1921-1939." pp. 150-151: Lappage. "Sport as an Expression of Westem and Maritime Discontent Between the Wars." $p$. 66. 
hoped that continued profits would compensate for that disappointment. It auicklv became apparent. however. that Maritimers were not willing to pay the price for top quality senior hockey without the grail of the Allan Cup in the spring ahead. Attendance fell drastically and the Beavers dropped out of the league. The remaining teams then decided to capitulate to the CAHA's demands by dropping their ineligible players and forming a makeshift amateur league. The changes came too late for the Moncton Hawks. who soon also folded. leaving the Wolverines and the Abegweits to represent the 'Big Four League' in the MAHA. The Wolverines defeated the decimated Abegweits and then easily handled the Edmundston Eskimos to earn the right to enter the Allan Cup playdowns."

This was especially significant for the city of Halifax. which had won the right to host the Allan Cup tinals. the first time that this had been awarded to a Maritime city. The Wolverines. as hosts. were spared from competing in the first round. The second round. however. saw them come up against a very strong Montreal Royals team that was expected to capture the cup that year. Instead. the Wolverines emerged from the semi-finals with victories of 4-4, 3-4, 4-2. and 7-2 (for a $2-1$ series win).$^{2+}$ The semi-finals were so rough that Clarence Campbell. a

"The Hallfax Herald. (1 December 1934). p. 9: (7 December 1934). p. 11: (17 December 1934). p. 9: (19 December 1934). p. 9.

"Alex Nickerson. "The 1935 Halifax Wolverines: Rainbow's End and Embitterment" in . Vora Scotia Sports Heritage ('entre. (September 1982). pp. 29-30. 
well respected referee from Saskatchewan who later became president of the NHI. was rushed to Halifax to officiate the final series." In this series the reputedly slow-footed Wolverines used their superior size to good advantage. stifling the speedy but slight Port Arthur Bearcats' attack en route to 3-2 and 4-3 victories. thus winning both the Allan Cup and the right to represent Canada at the Olympics.

The Maritimes. however. were feartul that the opportunity to represent Canada at the Olympics would be stripped from them. despite repeated assurances by the COC during the summer and fall that the Wolverines would be recognised as Canada's entry. ${ }^{26}$ However. these pronouncements by the $\mathrm{COC}$ assumed that the tate of the Halitax Wolverines as a team was secure. This was not the case. The Big Four League had suffered severe financial losses the year before and the various teams were hesitant to enter the fray once again for the 1935-1936 season. This left the Wolverines with no league to play in. Not only that. but six of their players had opted to play elsewhere for the upcoming season: two of them turning p!ofessional in the American Hockey League (AHL) and the other four signing with a senior team in Sudbury: Ontario. This lett Wolverines' manager Jack Conn

"ibid. p. 30.

$\therefore$ The Halifar Herald. (4 July 1935). p. 9:127 September 1935). p. 9:(10 October 1935). p. 8: (t November 1935), p. 9. 
with little choice but to fold the team. therebv eliminating anv chance that the Wolverines would gn to the Olympics. ${ }^{27}$

The COC soon announced that Canada would instead be represented by the previous year's losing Allan Cup tinalist. the Port Arthur Bearcats. with the promise that the few remaining Wolverines would be given first consideration should it be deemed necessary to bolster the Port Arthur squad. One of those Wolverines was Emie Mosher of Windsor. Nova Scotia who was pessimistic of his chances of going to the Olympics: "When the time comes to select the plavers to strengthen Port Arthur Bearcats," he asked. "who from the Maritimes will be on the committee to protect the interests of Bubar. Ferguson. Lawlor and myselt?" There was also consternation in Montreal over the choice of the Bearcats. many in that city believing that their Royals should have been selected. since it had been common consensus going into the Allan Cup the year betore that they were the superior team and also because they had given the Wolverines a closer contest than had the Bearcats. Eventually. E. A. Gilroy worked out a compromise. The Bearcats would continue to be Canada's representative. but they would be heavily reinforced with players from other squads. Ultimately the team selected consisted of tive Bearcats. four Wolverines (Sylvester "Daddy" Bubar. Vince Ferguson. 
"Chummie" Lawlor. and Emie Mosher). two Rovals. and one plaver from North Battleford."*

This selection of players gathered in Port Arthur in early December 1935 for training and to play a few exhibition games before departing for Germany. The four Wolverines seemed to get along well with the Bearcats and Rovals despite complaints of the year before about the Wolverines' unnecessarily rough play. The plavers later reported that the town of Port Arthur had taken them in as their own. and the Port Arthur News Chronicle praised their behaviour. ${ }^{2 y}$ There was no intimation that anything was amiss. and all expectations were for an uneventful and hopefully triumphant trip to Europe.

Then. as the team rested in Toronto on 6 January 1936. the announcement was made that the four Wolverines had been dropped from the Olympic squad. The players were indignant at this report. as were the Maritime hockey authorities. immediately assuming that this was an attempt by the CAHA to deny the Maritimes representation on the Olympic team. Suspicions of behind the scenes irregularities were encouraged by the fact that Lou Marsh of The Toronto Daily Star had published the details of the players' dismissal hours betore the meeting at which that dismissal had been officially decided. The Wolverines had

"ihid. (20 November 1935). pp. 1. 9: (27 Vovember 1935). p. 5: (3 December 1935). p. 11: (5 December 1935). p. 9: (7 December 1935). p. 9: (9 December 1935). p. 9.

thid. (9 January 1936). pp. I. 9: The Vews ( hronicle (Port Arhur). ( 8 January 1936). p. 8. 
seen this story the afternoon before that meeting and had immediatelv went to see E. A. Gilrov about the matter. only to be assured that the story was inaccurate.

A few hours later they were officially dropped from the team on the grounds that they had asked for support for their families while they were in Germany. The Wolverines did not deny that they had asked for money for their families. but stated that they had been promised this money when they were asked to join the team. and that it had been Gilroy himself who had brought up the subject as they were on the train from Port Arthur to Toronto. In fact. the initial comments of the players were all complimentary of Gilroy. the players saying that they believed Gilroy had been sincere in his expressions of concern for their families' well being. Only later did they change their opinions of Gilroy. as they remembered that he. in spite of his expressions of sympathy at the meeting. had used his illness (pleurisy) to avoid their questions. going into spasms whenever the plavers tried to press home an inquiry."

The citizens of Windsor were. according to The Halifar Herald. considerably more sceptical. Indeed. they perceived a tull blown conspriacy. a view with which The Herald's sports editor was obviously sympathetic:

It is remembered that sport authorities in Halifax charged that there was deliberate "raiding" of the Wolverines and Moncton Hawks for the purpose of preventing Wolverines trom going to the Olympic games as a unit and the invitations to the Maritime quartet came so

The Halifax Herald, $(7$ January 1936). p. 9: (8 January 1936). pp. 1. 8: (9 January 1936). pp. I.

9: The Vews ( hronicle. (8 January 1936). p. 8. 
reluctantlv. as to indicate. in the light of present develnnmente that there was no sincerity in the invitations, but that the present unfortunate home-coming of the Maritime quartet was arranged ivi even before they left to join the Port Arthur aggregation. ${ }^{\text {it }}$

This was one issue on which the Liberal Halifax Chronicle. despite an editorial policy less committed to regional protest. found itself in agreement with its Conservative rival..$^{32}$ Like The Herald. The Chronicle's sports section saw a regional dimension. if not an actual conspiracy. in Gilrov`s actions. W. J. Foley. Sports Editor of The Chronicle. wrote:

There will be no repeal: the matter is detinitely settled. and we in the Maritimes are not only left "holding the bag" but have with us that sinking feeling that once again Central Canada has sunken its iron talons into these seaward provinces and made us like it.

FROM WHERE WE SIT. the four ejected players were entirely within their rights for asking for protection for their families while they journeved abroad and waved Maple Leats in tront of confounded Europeans and Uncle Sam's chosen hockey disciples.

Despite official statements to the contrary. Canadian athletes chosen to represent their great country in sports abroad have always been cared for. In the majority of cases the athletes have been young and unmarried and did not have to leave behind families and dependents. but now that the time has come that married men are considered good enough to represent their country some provision should be made for those they leave behind. . . .

"The Halifar Herald. (9 January 1936), p. 9.

"For a discussion of The Haltfar Herald's editorial policy in comparison with that of the Haltfar ('hronicle see William March. Red Line: The ('hronicle-Herald and the Mal-sitar 1. $5-5-1957$. (Halifax. Nova Scotia: Chebucto Agencies Limited 1986). especially pp. 13-132. 166-170. 183-196 for the Maritime Rights Movement. 
Nova Scotians have been indignant betore when Central Canadians have trodden on their corns because they held the whip. but never so indignant as they are at the present time. ${ }^{\sharp 3}$

In Toronto the rival newspapers were also in agreement. but took the stance that the matter was solely one of avoiding professionalism. The Globe of Toronto argued that once the players had asked for broken time payments the CAHA had had no choice but to dismiss them. ${ }^{*}$ The Toronto Daily Star was even more emphatic. Sports editor Lou Marsh was known for his rigid stance against the practice of 'shamateurism. He was not opposed to professionals per se. nor did he share the common objection to amateurs competing with professionals. but he did vehemently decry any breaking of the strict amateur code which had been established by the AAU of $\mathrm{C}$ and adopted by the CAHA. He was thus in complete support of Gilroy`s uncompromising stance against the Wolverines` request tor broken time payments. His fervent support for Gilroy and the CAHA drew the comment that he was "leading the Gilroy claque in the Toronto Star" from Baz O'Meara. sports editor of The Montreal Daily Star. ${ }^{35}$

\footnotetext{
The Halifax ( hroncle. (9 January 1936). p. 7.

-The (ilobe (Toronto). (7 January 1936). p. 6: (8 January 1936). p. 6.
}

"The Montreal Datly Star. (11 February 1936). p. 27: Morrow. "Lou Marsh." pp. 24-28: The Toronto Datly Star. (7 January 1936). pp. 8-9: (10 January 1936). p. 14: (11 January 1936). p. I2: 6 Februany 1936). pp. It-15. 
Montreal newspapers were harshly critical of the CAHA's handling of the selection of the Olympic team. Leading the way was $\mathrm{O}^{\prime}$ Meara. whose rationale was that it should be the Montreal Rovals who got the chance to represent Canada since it was they who had given the Wolverines a much closer series in the semi-finals than had the Port Arthur Bearcats in the tinals. At the very least. he argued. the two teams should be forced to face each other for that right. ${ }^{\text {in }}$ This sentiment was echoed in the pages of La Presse. where it was recognised that the support for the Bearcats had a regional aspect:

On dit que tout l'Ouest sera en taveur du Port-Arthur s'il ne s'agit que du vote des différentes succursales. Cependant on croit que I'Ontario et les Provinces Maritimes supporteront le Royal. Si l'on décidait de faire jouer une série pour décider de la question elle aurait lieu à Toronto. Montréal ou Ottawa. ${ }^{57}$

The regional bias in the selection of the Bearcats was equally evident to O'Meara. who claimed that it was the result of Gilroy's status as a western hockey official with political aspirations. he having once run for Parliament. ${ }^{\$ \$}$ As a supporter of the Rovals. O'Meara was pleased that the banishment of the Wolverines would result in their being replaced by players from Montreal. He could well understand.

\footnotetext{
"The Lifontreal Dauly Siar. (22 Novembet 1935). p. 19: (27 November 1935). p. 31.
}

"La Presse (Montreal). (18 November 1935). p. 22: (25 November 1935). p. 18.

"The .tontreal Datly Star. (29 November 1935). p. 34. 
however. the negative reaction which the news of the Wolverines' banishment would receive in the Maritimes:

The Maritimes will be seething again just when the hockey heads had hockey fans down there tranquil once more. When a Maritimer starts to seethe he is a major league seether. When they move in titi mass it is time to start for the storm cellars. They have grand kind people down in that part of the world. the very salt of the earth. but when they get mad look out. So dear old President Gilroy will have burning ears again today. ${ }^{39}$

As one might expect. the strongest support for the Maritime position outside of that region came from westem Canada. The Edmonton Bulletin's Bill Lewis called the AAU of C the "most age-worn fossil of sport in this country" because of its 'simon-pure' stance with regard to amateurism. Hal Straight of The Vancouver Sun was even more clear. stating that it was only right that the Halifax players receive money for their efforts. further commenting that it was hypocritical of the CAHA to apply such a strict interpretation of amateurism at this time when they had so long neglected to do so previously. The Edmonton Bulletin also saw in the attempt of the Montreal Rovals to be named as Canada's representative another example of the east [central Canada] wanting to dominate amateur hockey."

\footnotetext{
ibud. (7 January 1935). p. 19.
}

"The Edmonton Bulletin. (22 November 1935). p. 12: (26 November 1935). p. 14: (7 January 1936). p. 14: The lancouver Sun. (8 January 1936). p. 15. 
A major exception was Winnipeg which was still smarting from the recruiting efforts of the Moncton Hawks in that city a few years previous. The Winnipeg Free Press had no sympathy for the plight of the Maritimers. Columnist W. G. Allen sneered at the idea that it had been Gilroy who had broached the topic of broken time payments. The Free Press also published an editorial cartoon bearing the caption "We Won't Go There Any More" and depicting the Wolverines as getting slapshotted out of the Olympic Games' back door by Canadian Amateur Hockey to the general amusement of bystanders. ${ }^{41}$

The four Wolverines had few options available to them. Gilrov and the CAHA. with the blessing of the COC. were the ones responsible tor the selection of the Olympic hockey team and there was no one above this level to whom they could appeal. Nevertheless. upon their return to Halifax each of the four prepared an affidavit stating their version of events. The affidavits of Lawlor. Mosher, and Ferguson each ended with the statement:

I do hereby solemnly swear that at no time did I ever mention the matter of family remuneration to any member of the Olympic team or to any member of Canada's governing sports bodies. In each case. where the matter was mentioned. it emanated trom an official in charge of the team.

Gilroy. for his part claimed that he had not wanted to provide a statement of events in the hope of sparing the players any embarrassment. but that he was

"The Hinnipeg free Press. (9 January 1936). p. 12: (11 January 1936). p. 23. 
willing to do so if that was their desire. ${ }^{12}$ He had been more outspoken a few days earlier. however. labelling MAHA president Jimmy Wry and Wolverines' manager Jack Conn as being simply "no good." Even when CAHA secretary Fred Marples tried to convince him to soften his words. Gilroy remained adamant. exclaiming that he would tell them the same when next he saw them. ${ }^{\text {t3 }}$ This only helped further belief that the Wolverines were the victims of a malicious conspiracy. When Gilroy eventually arrived in Halifax with the newly retooled Olympic team he was immediately beset by MAHA officials. whom Foley of The Halifar Chronicle depicted as representing "Maritime Rights." The results of the meeting were described by Wry as "unsatisfactory." adding further that the MAHA had considered resigning from the CAHA but had felt that doing so would have only exacerbated the situation. ${ }^{+4}$

That meeting had been the last gasp of the attempt to reinstate the four Wolverines. There remained only one very limited source of satisfaction for the Maritimes. The Olympic team was scheduled to play an assortment of Nova Scotia all-stars in Halifax prior to their departure for Europe. The hope was that the four Wolverines would get the opportunity to play for the Nova Scotian squad

$\because$ The Halifar Herald. (13 January 1936). pp. I. 9.

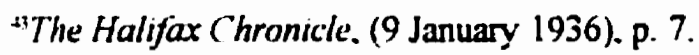

-ihud. (20 January 1936). p. 7. 
in this exhibition game. This hope. however, was extinguished by the CAHA. which expressly forbade their participation. When asked for an explanation by Wry, Gilroy answered that he did not know why these four had been refused permission to play. This sent Foley into new paroxysms of outraged disbelief:

The answer . . . is ABSURD. . . If the men who control hockey in this broad Dominion do not know, WHO DOES KNOW? WHO WOULD KNOW? .. I've been around a while myself and I never heard such a ridiculous thing in my life.

The hockey officials made a ruling and they don't know why they made it. ${ }^{45}$

Alex. E. Nickerson. the new Sports Editor of The Halifax Herald. did have a suggestion, claiming that Bearcats and Olympic team manager Malcolm Cochrane had feared that some of his players might be injured were the Wolverines to be allowed to skate against them. Halifax fans could only vent their frustration in an exhibition game between local players (sans Wolverines) and the Olympic team in their city. The game itself was a remarkably tame affair. with just two minor penalties being called throughout. The Globe. out of Toronto. reported that the crowd at the Halifax Forum showered the Forum ice with bottles and had generally treated the Olympic team as an enemy side. The Halifar Chronicle took umbrage at this description. While not denying that the crowd had been hostile to the Olympic squad. it pointed out that the two bottles thrown onto the ice hardly

“ibid. (20 January 1936). p. 7.

The Halifar Herald. (20 April 1936). p. 9. 
constituted a shower. It also observed that the nature of the bottles thrown indicated that their throwers had been intoxicated. and that while it could not condone such an action it could certainly understand, given the circumstances. how a man under the influence of alcohol could have allowed his just indignation to get the better of him. $^{47}$

The Port Arthur Bearcats and additions then travelled to Garmisch-Partenkirchen. where they stormed through the first round. easily: defeating Poland. Latvia. and Austria by scores of 8-1, 15-0. and 5-2 respectively. They then advanced to the second round, where their first game was against the United Kingdom. a team with which Canada was already embroiled in controversy. Eleven of the thirteen members of the United Kingdom's team were recently transferred Canadians, three of whom E. A. Gilroy felt should have been ineligible to play because they had not been granted permission by the CAHA to transfer outside of Canada. The British argued that the CAHA had no right to set restrictions more stringent than those of the International Ice Hockey Federation (IIHF). which were simply that players were free to transter between seasons without the necessity of first gaining permission. Gilroy's stance was that each national federation should respect the regulations of the other national federations. He was supported in this by the influential Avery Brundage of the United States. and the three British plavers were disqualified by a vote of $47-0$

${ }^{37}$ The Halifax ( hronicle. (22 January 1936). p. 7. 
with three abstentions. Gilroy was condemned by both the British and Maritime press for bringing up this issue on the eve of the Olympics. The Telegraph Journal commenting that Gilroy was even chasing away former Maritimers. noting that Jimmy Foster (formerly of the Moncton Hawks by way of Winnipeg) and Alex Archer (formerly of the Saint John Beavers) were two of the plavers in question. However. once Gilrov had won his point. he magnanimously dropped his objections to the players and allowed them to compete. ${ }^{+3} \mathrm{He}$ may have regretted this. as the game against the United Kingdom saw the unthinkable. Canada being defeated 2-1. Ironically. it was the play of goalie Jimmy Foster which was held to be largely responsible for the United Kingdom's victory. Canada's two other second round games were easy 15-0 and 6-2 wins over Hungary and Germany. Then. in the final round. came the final shock. Canada beat Czechoslovakia 5-0 and the United States 1-0 but were denied a rematch with the United Kingdom. That team. on the strength of a scoreless tie with the United States and a victory over Czechoslovakia in addition to a carry over of two points from their victory over Canada in the second round. won the gold medal. This left Canada with the silver and the United States with the bronze. The

\footnotetext{
"anonymous. The Olympic Sion: Pursult of Excellence. (Danbury. Connecticut: Grollier Enterprises Inc.. 1979). pp. 143-144: -Minutes of the Nineteenth Annual Meeting. Canadian Amateur Hockey Association. 1936." (Toronto. Ontario: 10-14 April 1936). G. S. Dudley Files. National Archives of Canada pp. 12-16: The Telegraph Journal (Saint John). (6 February 1936). p. 8: The Toronto Dally Siar. 16 February 1936). p. 15.
} 
Canadian officials at the Olympics. headed by E. A. Gilrov. were appalled to learn that thev would not get the opportunity to face the United Kingdom again in the final round. The rules of that year. however. were that games plaved in earlier rounds between teams which would later make the final pool would count towards the final round robin. thus no teams would face each other twice over the course of the tournament. Gilroy claimed that he had only discovered this rule after the loss to the United Kingdom in the second round. and immediately asked that it be changed. The eight teams who remained in the tourney met to discuss the issue and rejected Canada's request by a vote of 6-2. Germany alone siding with Canada. The United States stated firmly that the middle of a tournament was no time to be changing the rules. Gilroy argued that the rule had in fact already been changed after the United Kingdom had defeated Canada. and that all he wanted was the original rule again. but to no avail." The Halifar Herald took a perverse pleasure at this turn of events. declaring that Gilrov's lack of understanding of the points system was just another example of his incompetence. adding: "Too late C.A.H.A. officials realize the blunder that every unbiased fan in Canada knew was heing made months ago when the Bearcats were first named. ${ }^{\text {st) }}$

\footnotetext{
-... Minutes of the Nineteenth Annual Meeting." pp. 16-18: Thic Toruniti Daily Siar. 113 February 1936). p. 15: (14 February 1936). p. 12.

The Haltax Herald. 115 February 19361. p. II.
} 
In December 1936 the CAHA withdrew its membership from the AAII of $C$. The issue in dispute between the two bodies was broken time pavments. The CAHA wanted them to be made legal. while the AAU of C remained stubbornly 'simon-pure.' In fact. in April 1936. just two months after the Winter Olympics. the CAHA unanimously approved a resolution stating that "payment to hockey players by clubs or emplovers for time lost from work while plaving games would be permitted." Alan Metcalfe has correctly interpreted this and other resolutions made that day as signifying the death in Canadian hockey of the simon-pure" amateur ideal. His argument is that the amateur ideal had become outdated. that the increase of upenly professional hockey in Canada and the United States made it impossible to follow such a restrictive code. Surprisingly. he fails to mention the shock of losing the gold medal in 'Canada's game' as the trigger which forced the CAHA out of its inertia. ${ }^{51}$

For the Maritimes there was only bitterness. They had produced and supported teams which were the finest in the nation outside of the NHL. It was their belief that that these had been undermined through the machinations of central Canadian officials. These officials and their policies had destroyed their

\footnotetext{
Alan Metcalfe. "1937: The Demise of Amateurism in Canada" in Sandra Kereliuk. ed.. The University's Role in the Development of Modern Sport: Past. Present. and Furure. Proceedings of the FISL: Conference-lintiersiade $\times 3$ in .Assoctation wh the Tenth HISP'A conference. (Edmonton. Alberta: University of Alberta 1983). pp. 308-315: -Minutes of the Nineteenth Annual Meeting.” pp. 19-31.
} 
league. destroyed their team just when it was on the verge of Olympic glory. and had even denied their region a token representation on the team which did represent Canada. As the Maritimes had discovered with the Maritime Rights Movement in the realm of political econmy. their efforts to compete at a national level often seemed to founder against the greater influence of larger regions. According to Forbes, the Maritime Rights Movement ended for many regionalists in disillusionment and cynicism. ${ }^{52}$ A similar fate now betell the campaign tor the Allan Cup. As Alex. E. Nickerson later put it:

There was a time when the Allan Cup and Maritime Rights were synonomous. Familiarity and the remembrance of the countless underhanded stratagems to keep that trophy from the Maritimes has bred contempt. and there will be no gnashing of teeth when the Allan Cup departs. many hope forever. from the seaside provinces.

On 22-23 March 1936 the Moncton Maroons were defeated 6-3 and 7-1 by the Brockville (Ontario) Magedomas in the first round of the Allan Cup playdowns."

'Forbes. The Martume Rights Movement. 1919-192:- pp. 190-192.

"The Halitax Herald. (5 March 1936). p. 11.

ibiel. (23 March 1936). p. 8:(24 March 1936). p. 8. 


\section{Bibliography}

I. Newspapers

The Charlottetown Guardian. (November 1935 - February 1936).

The Edmonton Bulletin. (November 1935 - February 1936).

The Globe (Toronto). (November 1935 - February 1936).

The Halifax Chronicle. (November 1935 - February 1936).

The Halifax Herald. (January 1931 - April 1931). (January 1933 - June 1936).

The Moncton Daily Times. (November 1935 - February 1936).

The . Kontreal Daily Star. (November 1935 - February 1936).

The News Chronicle (Port Arthur). (November 1935 - February 1936).

La Presse (Montreal). (November 1935- February 1936).

The Telegraph Journal (Saint John). (November 1935 - February 1936).

The Toronto Daily Star. (November 1935 - February 1936).

The Vancouver Sun. (November 1935 - February 1936).

The Winnipeg Free Press. (November 1935 - February 1936).

II. Primary Sources

Official tithletic Rules and Handbook of the Amateur Athletic Lnion of Canada1937.

1930 Official Hockey Rules. Canadian Amateur Hockey Association. Constitution By-laws and Regulations. Rules Governing tllan Cup and O.H.A. Lemorial Trophy Games. Playing Rules of the Game. 
1935 Official Hockey Rules. Canadian tmateur Hockey .tssociation. Constitution By-laws and Regulations. Rules Governing Allan Cup and O.H.A. Memorial Trophy Games. Playing Rules of the Game.

Canadian Hockey Association. 1995-1996. Constitution By-lanvs Regulations History.

-Minutes of the Eighteenth Annual Meeting. Canadian Amateur Hockey Association. 1935." Halifax. Nova Scotia: 10-12 April 1935. G. S. Dudley Files. National Archives of Canada.

"Minutes of the Nineteenth Annual Meeting. Canadian Amateur Hockey Association. 1936." Toronto, Ontario: 10-14 April 1936. G. S. Dudlev Files. National Archives of Canada.

III. Secondary Sources

Acheson. T. W. "The Maritimes and "Empire Canada" in David Jay Bercuson. ed. Canada and the Burden of L'nity. Toronto. Ontario: Macmillan of Canada. 1977: 87-114

Alexander. David. "Economic Growth in the Atlantic Region. 1880 to $1940 "$ in Acadiensis. 8: I (Autumn 1981): 47-76.

anonymous. The Olympic Story: Pursuit of Excellence. Danbury. Connecticut: Grollier Enterprises Inc.. 1979.

Ashe. Robert. Even the Babe Came to Play: Small-Town Baseball in the Dirn. 30s. Halitax. Nova Scotia: Nimbus Publishing. 1981.

Bergasse. Sally P. "A Survey of the Concept of Amateurism in Canada." Unpublished MSc thesis. Springtield. Massachusetts: Springtield College. 1970

Bickerton. James. "Underdevelopment and Social Movements in Atlantic Canada: A Critique in Studies in Political Economy: .t Socialist Review. no. 9 (Fall 1982): 191-202.

Bickerton. James P. Vova Scotia. Ottawa. and the Politics of Regional Development. Toronto. Ontario: University of Toronto Press. 1990. 
Brym. Robert J.. and R. James Sacouman. eds. Underdevelopment and Social Movements in Atlantic Canada. Toronto. Ontario: New Hogtown Press. 1979.

Conrad. Margaret. "Apple Blossom Time in the Annapolis Vallev 1880-1957" in Acadiensis. 9: 2 (Spring 1980): 14-39.

Conrad, Margaret. "The Art of Regional Protest: The Political Cartoons of Donald McRitchie, 1904-1937" in Acadiensis. 21: I (Autumn 1991): 5-29.

Conrad. Margaret. "The Atlantic Revolution of the 1950s" in Berkeley Fleming. ed. Beyond Anger and Longing: Community and Development in Atlantic Canada. Sackville. New Brunswick: Centre for Canadian Studies. 1988: $55-96$.

Cosentino. Frank. "A History of the Concept of Professionalism in Canadian Sport" in Canadian Journal of History of Sport and Phisical Education. 6 : 2 (December 1975): 75-81.

Cosentino. Frank. “A History of the Concept of Professionalism in Canadian Sport." Unpublished PhD dissertation. Edmonton. Alberta: University of Alberta. 1973.

Fischler. Stan. and Shirley Walton Fischler. eds. The Hockey Encyclopedia: The Complete Record of Professional Ice Hockey. New York. New York: Macmillan Publishing Company, 1983.

Forbes. E. R. "The 1930s: Depression and Retrenchment" in E. R. Forbes and D. A. Muise. eds. The Atlantic Provinces in Confederation. Toronto. Ontario: University of Toronto Press. 1993: 272-305.

Forbes. E. R. "In Search of a Post-Confederation Maritime Historiography. 1900-196\% in Acadiensis 8: I (Autumn 1978): 3-2!

Forbes. Ernest R. "Cutting the Pie into Smaller Pieces: Matching Grants and Relief in the Maritime Provinces during the 1930s" in Ernest R. Forbes. Challenging the Regional Stereotype: Essays on the 20th Centun. . Laritimes. Fredericton. New Brunswick: Acadiensis Press. 1989: 148-171.

Forbes. Emest R. The Maritime Rights Movement: A Study in Canadian Regionalism. Kingston. Ontario: McGill-Queen`s University Press. 1979. 
Forbes. Emest R. "Misguided Symmetry: The Destruction of Regional Transportation Policy for the Maritimes" in David Jay Bercuson. ed. Canada and the Burden of Unity. Toronto, Ontario: Macmillan of Canada. 1977: 60-86.

Forbes. Ernest R. "The Origins of the Maritime Rights Movement" in Ernest R. Forbes. Challenging the Regional Stereotype: Essays on the 20th Century. .Maritimes. Fredericton. New Brunswick: Acadiensis Press. 1989: 100-113.

Francisco. Jennifer Dorothy. "New Brunswick Finances. 1917-1952." Unpublished MA thesis. Fredericton, New Brunswick: University of New Brunswick. 1992.

Frank. David. "The 1920s: Class and Region. Resistance and Accommodation" in E. R. Forbes and D. A. Muise. eds. The Atlantic Provinces in Confederation. Toronto. Ontario: University of Toronto Press. 1993. 233-27I.

Hattield. Michael. -J. B. M. Baxter and the Maritime Rights Movement." Unpublished BA report. Sackville. New Brunswick: Mount Allison University. 1970.

Howell. Colin D. Northern Sandlots: A Social History of Maritime Baseball. Toronto. Ontario: University of Toronto Press. 1995.

Jones. Kenneth Gary. "Response to Regional Disparity in the Maritime Provinces. 1926-1942: A Study in Canadian Intergovernmental Relations." Unpublished MA thesis. Fredericton. New Brunswick: University of New Brunswick. 1980.

Jones. Kevin G. "Developments in Amateurism and Professionalism in Early 20th. Century Canadian Sport" in Journal of Sport Histonv. 2: I (Spring 1975): $29-40$

Lansley, Keith L. "The Amateur Athletic Union of Canada and Changing Concepts of Amateurism." Unpublished PhD dissertation. Edmonton. Alberta: University of Alberta Press, 1971.

Lappage. Ron. "Sport Between the Wars" in Don Morrow. Mary Keves. Wayne Simpson. Frank Cosentino. and Ron Lappage. eds. A Concise Histon of Sport in Canada. Toronto. Ontario: Oxford University Press. 1989: 88-108. 
Lappage. Ronald S. "Selected Sports and Canadian Society 1921-1939." Unpublished PhD dissertation. Edmonton. Alberta: University of Alberta. 1974.

Lappage. Ronald S. “Sport as an Expression of Western and Maritime Discontent in Canada Between the Wars" in Canadian Journal of History of Sport and Physical Education. 8: I (May 1977): 50-7I.

March. William. Red Line: The Chronicle-Herald and the Mail-Star 1875-1954. Halifax. Nova Scotia: Chebucto Agencies Limited, 1986.

Metcalfe. Alan. "1937: The Demise of Amateurism in Canada" in Sandra Kereliuk. ed. The University's Role in the Development of .Modern Sport: Past. Present. and Future. Proceedings of the FISL Conference-Universiade 83 in Association with the Tenth HISP.A Conference. Edmonton. Alberta: University of Alberta. 1983: 308-315.

Metcalte. Alan. Canada Learns to Plan: The Emergence of Organized Sport. 1807-1914. Toronto. Ontario: McClelland and Stewart Limited. 1987.

Morrow. Don. "Lou Marsh: The Pick and Shovel of Canadian Sporting Journalism" in Canadian Journal of History of Sport. 14: I (May 1983): $21-33$.

Nickerson. Alex. "The 1935 Halifax Wolverines: Rainbow's End and Embitterment" in Nova Scotia Sports Heritage Centre. (September 1982): 29-30.

Rawlyk. G. A. "Nova Scotia Regional Protest. 1867-1967" in Queen's Quarterly. 75: 1 (Spring 1968): 105-123.

Sager. Eric "Dependency. Underdevelopment. and the Economic History of the Atlantic Provinces" in Acadiensis. 17:1 (Autumn 1987): 117-137.

Taylor. Kenneth Lyle. "The Pursuit of Industrial Development in New Brunswick and Saskatchewan. 1945-1960: A Comparative Study." Unpublished MA thesis. Fredericton. New Brunswick: University of New Brunswick. 1995.

Young. A. J. “Sandy." Beyond Heroes: A Sport Histon of Nova Scotia. Volume II. Hantsport. Nova Scotia: Lancelot Press. 1988. 